\title{
PENGARUH MOTIVASI, PERSEPSI DAN SIKAP KONSUMEN TERHADAP KEPUTUSAN PEMBELIA SEPEDA MOTOR PADA DEALER HONDA ASTRA MOTOR PALUR
}

\author{
Muhammad Naashir*, Istiatin ${ }^{1}$, Sri Hartono ${ }^{2}$ \\ naashirmen@yahoo.com \\ Fakultas Ekonomi Manajemen, Universitas Islam Batik Surakarta \\ Jl. KH. Agus Salim No. 10 Surakarta
}

\begin{abstract}
The aim of this research are 1) to analyse the influence of motivation, perception, and attitudes of consumers in together about the decision of the purchase on Astra Motor Honda Palur dealer 2) to analyze influence in partial motivation, perception and attitude of consumers on the performance of the purchase decision on dealer astra honda motor vehicle palur. The population in this research was consumers on dealer astra honda motor vehicle palur that is not boundless. In this research sample taken namely 100 respondents .Data collection techniques in this research using questionnaires and writer uses likert scale as a measuring instrument.Technical data analysis in this research uses linear regression worship of idols, $t$ test, test $f$, the coefficients determined.

The result of the research indicated that: 1) simultaneously variable motivation, perception, and attitude consumers influential of the decision the purchase by a dealer Astra Honda Motor Palur. 2) in partial variable motivation, preception and attitude consumers influential of the decision the purchase by a dealer Astra Honda Motor Palur.

Advised for the Honda Astra Motor Palur, psychology consumers need to pay attention to one of them is from the perspective of motivation, the perceptions and attitudes of consumers by improving the quality of honda motor be even better by using better material so that the quality of on a vehicle increased.
\end{abstract}

Keywords: psychological factors, motivation, perception, the consumer, the buyers.

\section{PENDAHULUAN}

Keputusan pembelian menjadi suatu hal yang penting untuk diperhatikan karena hal ini tentu akan menjadi suatu pertimbangan bagaimana suatu strategi pemasaran yang akan dilakukan oleh perusahaan berikutnya. Keberhasilan perusahaan dalam mempengaruhi konsumen dalam keputusan pembelian sangat didukung melalui upaya membangun komunikasi kepada konsumen dengan membangun merek kepada konsumen dengan strategi pemasaran, serta melakukan inovasi untuk varians- varians baru pada suatu produk. Sebelum pelanggan memutuskan untuk menggunakan produk terlebih dahulu melakukan pencarian informasi terkait produk yang dibutuhkan, setelah informasi didapat maka hal yang dilakukan adalah melakukan pengamatan terhadap produk tersebut, selanjutnya baru menentukan pilihan dan evaluasi. Semua proses tersebut bisa disebut dengan perilaku konsumen.

Menurut Swastha dan Irawan ialah kebudayaan, kelas sosial, 
kelompok referensi kecil, keluarga, pengalaman, kepribadian, sikap dan kepercayaan, dan konsep diri. Sehubungan dengan hal tersebut, perusahaan perlu menerapkan studi perilaku konsumen pada kegiatan pemasarannya. Tujuan utama mempelajari perilaku konsumen bagi produsen atau perusahaan adalah untuk memahami mengapa dan bagaimana konsumen mengambil keputusan pembelian. Dengan adanya pemahaman tentang keputusan pembelian dapat memberikan kemudahan bagi perusahaan untuk merencanakan strategi pemasaran. Produk yang ditawarkan oleh perusahaan dapat menjadi salah satu pembentukan motivasi, persepsi dan sikap konsumen dalam melakukan pengambilan keputusan pembelian.

Seiring dengan perkembangan jaman dan semakin meningkatnya kebutuhan alat transpotasi membawa angin segar bagi perusahaan otomotif terutama dibidang sepeda motor, hal ini sangat dibutuhkan oleh banyak orang selain harganya terjangkau dan mudah perawatannya. Saat ini banyak sekali bermunculan merk sepeda motor dengan berbagai model, desain, memberikan kualitas yang bagus dan harga yang cukup bersaing. Bagi perusahaan yang bergerak dibidang otomotif hal ini merupakan suatu peluang untuk menguasai pangsa pasar. Salah satu merk yang digemari oleh sebagian masyarakat sejak dahulu adalah merek Honda. PT Astra Honda Motor (AHM) merupakan pelopor industri sepeda motor di Indonesia. Tipe sepeda motor yang pertama kali di produksi Honda adalah tipe bisnis, $\mathrm{S} 90 \mathrm{Z}$ bermesin 4 tak dengan kapasitas $90 \mathrm{cc}$. Jumlah produksi pada tahun pertama selama satu tahun hanya 1500 unit, namun melonjak menjadi sekitar 30 ribu pada tahun berikutnya dan terus berkembang hingga saat ini.

Lokasi yang dipilih adalah pada dealer Honda Astra Palur Karanganyar, karena merupakan dealer yang khusus melakukan penjualan sepeda motor honda Adapun obyek yang diteliti adalah konsumen yang membeli sepeda motor honda pada dealer honda astra motor palur. Alasannya karena berkembangnya pengguna sepeda motor honda di karanganyar saat ini tinggi.

\section{TINJAUAN TEORITIS \\ Keputusan Pembelian}

Menurut Kotler dan Keller (2009: 188) keputusan pembelian dalam tahap evaluasi, konsumen membentuk preferensi antar merek dalam kumpulan pilihan. Keputusan pembelian merupakan suatu kegiatan individu yang secara langsung untuk mendapatkan dan mempergunakan barang yang ditawarkan.

Konsumen dapat membentuk niat untuk membeli merek yang paling disukai. Namun, ada dua faktor yang dapat berada di antara niat pembelian dan keputusan pembelian, yaitu sikap dan faktor situasi yang tidak terantisipasi, Kotler (2005: 227).

Para pemasar harus memahami faktorfaktor yang menimbulkan perasaan dalam diri konsumen akan adanya resiko dan memberikan informasi serta dukungan untuk mengurangi resiko yang dipikirkan itu, Kotler (2005: 227).

\section{Proses Pengambilan Keputusan Konsumen}

Ketika membeli produk, secara umum konsumen mengikuti proses pengambilan keputusan yaitu pengenalan kebutuhan pencarian informasi, evaluasi alternatif, pembelian, dan perilaku pasca pembelian. Proses pengambilan keputusan konsumen dapat diuraikan sebagai berikut, Lamb (2001:189) :

1. Pengenalan kebutuhan terjadi ketika konsumen menghadapi ketidakseimbangan antara keadaan sebenarnya dan keinginan.

2. Pencarian informasi 
Setelah mengenali kebutuhan atau keinginan, konsumen mencari informasi tentang beragam alternatif yang ada untuk memuaskan kebutuhannya.

3. Evaluasi alternatif Konsumen akan menggunakan informasi yang tersimpan di dalam ingatan, ditambah dengan informasi yang diperoleh dari luar untuk membangun suatu kriteria tertentu.

4. Pembelian

Sejalan dengan evaluasi atas sejumlah alternatif-alternatif tadi, maka konsumen dapat memutuskan apakah produk akan dibeli atau diputuskan untuk tidak dibeli sama sekali.

\section{Pengertian Perilaku Konsumen}

Perilaku konsumen didefinisikan sebagai perilaku yang konsumen tunjukan dalam mencari, membeli, menggunakan, mengevaluasi, dan menghabiskan produk dan jasa yang mereka harapkan dapat memuaskan kebutuhan mereka, Kanuk \& Schiffman (2010: 23).

Perilaku konsumen adalah kegiatan-kegiatan individu yang secara langsung terlibat dalam mendapatkan dan mempergunakan barang-barang dan jasa termasuk didalamnya proses pengambilan keputusan pada persiapan dan menentukan kegiatan-kegiatan tersebut, Kotler ( 2002: 52)

Perilaku konsumen memiliki kepentingan khusus bagi orang yang karena berbagai alasan, berhasrat mempengaruhi atau mengubah perilaku itu, termasuk mereka yang kepentingan utamanya adalah pemasaran, pendidikan dan perlindungan konsumen serta kebijakan umum. Pemahaman aspekaspek konsumen tersebut aqkan memberikan dasar bagi penyusunan strategi pemasaran dimasa kini dan masa datang. Beberapa implikasi penting dari perilaku konsumen bagi arah kebijakan pemasaran adalah sebagai berikut:
1. Mendefinisikan dan mensekmentasi pasar.

2. Menentukan kebutuhan dan keinginan dari segmentasi pasar.

3. Mengembangkan strategi yang didasarkan pada kebutuhan, sikap dan persepsi konsumen.

4. Mengevaluasi strategi pemasaran.

5. Menilai perilaku konsumen dimasa yang akan datang, sutisna (2003: 7)

Faktor-faktor yang Dapat Mempengaruhi Perilaku Konsumen Menurut Swasta dan Handoko (2000: 58) Faktor internal yang dapat mempengaruhi perilaku konsumen antara lain :

1. Motivasi

Menurut Schiffman dan Kanuk (2000: 69) motivasi adalah The Driving force with in individual that impels then to action. Motivasi merupakan kekuatan penggerak dalam diri seseorang yang memaksanya untuk bertindak.

Menurut Handoko (2001: 225) mengatakan bahwa motivasi adalah suatu keadaan dalam pribadi yang mendorong keinginan individu untuk melakukan keinginan tertentu guna mencapai tujuan.

Menurut Sigit (2002: 17) menjelaskan bahwa motivasi pembelian adalah pertimbangan pertimbangan dan pengaruh yang mendorong orang untuk melakukan pembelian. Dalam motivasi pembelian terbagi menjadi motivasi rasional dan emosional.

Motivasi rasional adalah pembelian yang didasarkan kepada kenyataankenyataan yang ditunjukkan oleh produk kepada konsumen dan merupakan atribut produk yang fungsional serta obyektif keadaannya misalnya kualitas produk, harga produk, ketersediaan barang, efisiensi kegunaan barang tersebut dapat diterima.

Motivasi emosional dalam 
perasaan, kesenangan yang dapat ditangkap oleh pancaindera misalnya dengan memiliki suatu barang tertentu dapat meningkatkan status sosial, peranan merek menjadikan pembeli menunjukkan status ekonominya dan pada umumnya bersifat subyektif dan simbolik. Pada saat seseorang akan mengambil keputusan untuk membeli suatu produk tentunya akan dipengaruhi oleh kedua jenis motivasi tersebut yaitu motivasi rasional dan emosional.

2. Persepsi

Menurut Schiffman dan Kanuk (2000: 146) Perception is process by which an individuals selects, organizers, and interprets stimuli into the a meaningfull and coherent picture of the world. Kurang lebihnya bahwa persepsi merupakan suatu proses yang membuat seseorang untuk memilih, mengorganisasikan dan menginterprestasikan rangsangan rangsangan yang diterima menjadi suatu gambaran yang berarti dan lengkap tentang dunianya.

Menurut Kotler dan Amstrong (1996: 156) mengemukakan bahwa dalam keadaan yang sama, persepsi seseorang terhadap suatu produk dapat berbeda-beda, hal ini disebabkan oleh adanya proses seleksi terhadap berbagai stimulus yang ada.

Pada hakekatnya persepsi akan berhubungan dengan perilaku seseorang dalam mengambil keputusan terhadap apa yang dikehendaki. Salah satu cara untuk mengetahui perilaku konsumen adalah dengan menganalisis persepsi konsumen terhadap produk. Dengan persepsi konsumen kita dapat mengetahui hal-hal apa saja yang menjadi kekuatan, kelemahan, kesempatan ataupun ancaman bagi produk kita.

3. Sikap Konsumen

Menurut Robbins (2006: 169) sikap adalah pernyataan-pernyataan atau penilaian evaluatif berkaitan dengan obyek, orang atau suatu peristiwa.

Simamora (2002: 14) Mengatakan bahwa di dalam sikap terdapat tiga komponen yaitu :

Cognitive component

Kepercayaan konsumen dan pengetahuan tentang obyek. Yang dimaksud obyek adalah atribut produk, semakin positif kepercayaan terhadap suatu merek suatu produk maka keseluruhan komponen kognitif akan mendukung sikap secara keseluruhan.

\section{Affective component}

Emosional yang merefleksikan perasaan seseorang terhadap suatu obyek, apakah obyek tersebut diinginkan atau disukai.

Behavioral component

Merefleksikan kecenderungan dan perilaku aktual terhadap suatu obyek, yang mana komponen ini menunjukkan kecenderungan melakukan suatu tindakan.

\section{KERANGKA KONSEPTUAL DAN HIPOTESIS}

Sebagai gambaran dalam penyusunan penelitian ini, maka diperlukan adanya sebuah kerangka pemikiran yang terperinci agar pemecahan masalah ini dapat terarah, maka dapat dilihat pada gambar berikut :

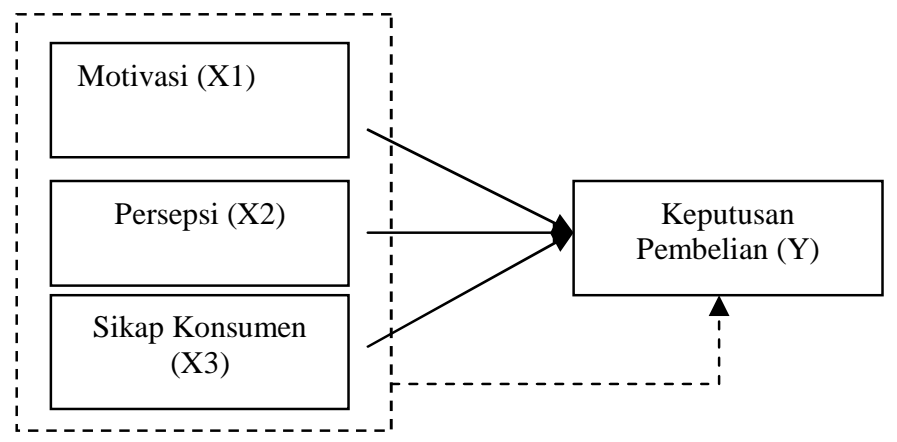


Dari kerangka pemikiran diatas dapat dijelaskan bahwa Motivasi $\mathrm{X}_{1}$ berpengaruh secara langsung terhadap Keputusan Pembelian sebagai Y sehingga menghasilkan hipotesis, kemudian Persepsi sebagai $\mathrm{X}_{2}$ berpengaruh secara langsung terhadap Keputusan Pembelian sebagai Y, dan Sikap Konsumen $\mathrm{X}_{3}$ berpengaruh secara langsung terhadap Keputusan Pembelian sebagai Y. Garis titik-titik diatas menunjukan bahwa variabel tersebut dilakukan bersama-sama atau disebut dengan simultan.

\section{Hipotesis}

1. Diduga ada pengaruh signifikan secara simultan motivasi, persepsi, dan sikap konsumen terhadap keputusan pembelian sepeda motor pada Dealer Astra Motor Honda Palur

2. Diduga ada pengaruh positif dan signifikan motivasi terhadap keputusan pembelian sepeda motor pada Dealer Astra Motor Honda Palur

3. Diduga ada pengaruh positif dan signifikan persepsi terhadap keputusan pembelian sepeda motor pada Dealer Astra Motor Honda Palur

4. Diduga ada pengaruh positif dan signifikan sikap konsumen terhadap keputusan pembelian sepeda motor pada Dealer Astra Motor Honda Palur.

\section{METODE PENELITIAN \\ Populasi dan Sampel}

Dalam penelitian ini yang menjadi populasi adalah tak terhingga atau seluruh konsumen Lokasi penelitian dilakukan di pada Dealer Astra Motor Honda Palur, karanganyar, jawa tengah. Sampel adalah sebagian atau wakil piupulasi yang diteliti. Sebagai materi hendaknya memiliki citri-ciri yang mirip populasi sehingga dapat menggambarkan keadaan populasi
(Arikunto, 2002: 109) Sampel yang diteliti dalam penelitian ini berjumlah 100 reponden. Tehnik yang digunakan adalah tehnik convenience sampling yaitu tehnik penentuan sampel berdasarkan pada ketersediaan elemen dan kemudahan untuk mendapatkanya (Sekaran Uma, 2006: 136)

\section{Teknik Pengumpulan Data}

Pengumpulan data dilakukan dengan observasi, dokumentasi, angket/kuesioner, dan wawancara. Observasi dilakukan pada tahap awal penelitian melalui pengamatan secara langsung terhadap objek penelitian. Kuesioner diberikan kepada responden dengan sistem tertutup. Wawancara dilakukan dengan memfotocopy sejumlah data sekunder yang telah didokumentasikan perusahaan seperti struktur organisasi beserta tugastugasnya

\section{Model dan Teknik Analisis}

Penelitian ini menggunakan analisis deskriptif dan analisis regresi berganda. Analsisi deskripsi memberikan gambaran tentang karakteritik responden dan variabel. Kemudian analisis regresi linear berganda (Multiple Regression Analysis) digunakan untuk menguji pengaruh variabel independen terhadap variabel dependen baik secara simultan maupun secara parsial. Adapun bentuk persamaan regresi dapat diformulasikan sebagai berikut : (Supawi dan Eny, 2011)

$$
\mathrm{Y}=\propto+\mathrm{b}_{1} \mathrm{X}_{1}+\mathrm{b}_{2} \mathrm{X}_{2}+\mathrm{b}_{3} \mathrm{X}_{3}+\mathrm{e}
$$

Dimana :

$$
\begin{array}{ll}
\mathrm{Y} & =\text { Keputusan Pembelian } \\
\mathrm{X}_{1} & =\text { Motivasi } \\
\mathrm{X}_{2} & =\text { Persepsi } \\
\mathrm{X}_{3} & =\text { Sikap Konsumen } \\
\propto & =\text { Bilangan Konstan } \\
\mathrm{b} & =\text { Slope }(\text { koefisien } \\
& \text { kecondongan } \beta \text { ) } \\
\mathrm{e} & =\text { Error }
\end{array}
$$


Dari persamaan regresi linear berganda tersebut diatas maka dilakukan uji statistic yaitu uji $F$, uji $t$, dan koefisien determinasi.

\section{Pengujian Hipotesis}

Untuk menguji hipotesis pertama digunakan uji $\mathrm{F}$, yaitu untuk menguji signifikansi pengaruh variabel independen secara bersama-sama terhadap variabel dependen. Pengujian dilakukan dengan cara melihat probabilitas nilai $\mathrm{F}_{\text {hitung. Jika }}$ probabilitasnya (sig.) $<0,05$, maka hipotesis penelitian diterima. Dalam hal ini dapat dikatakan bahwa variasi model regresi dapat menerangkan sejauh mana pengaruh bersama-sama antara variable motivasi, persepsi dan sikap konsumen terhadap keputusan pembelian. Sebaliknya jika probabilitas nilai $F_{\text {hitung }}$ $>0,05$, maka hipotesis penelitian ditolak. Hal ini berarti bahwa variasi dari model regresi tidak dapat menerangkan sejauh mana pengaruh bersama-sama variabel motivasi, persepsi dan sikap konsumen terhadap keputusan pembelian. Untuk mengetahui besarnya variable perilaku konsumen dalam menerangkan keputusan pembelian dapat dilihat dari besarnya koefisien determinasi $\left(\mathrm{R}^{2}\right)$.

Kemudian untuk membuktikan kebenaran hipotesis kedua dilakukan dengan menguji pengaruh variabel independen secara parsial terhadap variabel dependen. Pengujian dilakukan dengan cara melihat probabilitas nilai $t_{\text {hitung. }}$ Jika probabilitas menunjukkan $<0,05$ berarti bahwa ada pengaruh yang signifikan dari masing-masing variabel independen terhadap variabel dependen. Nilai $t_{\text {hitung }}$ yang lebih tinggi merupakan indikasi sebagai faktor yang paling berpengaruh terhadap keputusan pembelian.

\section{HASIL PENELITIAN DAN PEMBAHASAN}

Hasil perhitungan analisis regresi berganda dengan menggunakan program SPSS 16 disajikan pada Tabel 1.

Tabel 1

Hasil Analisis Regresi Berganda

\begin{tabular}{|c|c|c|c|c|}
\hline Variabel & $\mathrm{B}$ & Fror & & D \\
\hline Konstanta & 3.366 & 1.591 & 2.116 & 0.037 \\
\hline Motivasi & 0,419 & 0,073 & 5,756 & 0,000 \\
\hline persepsi & $-0,210$ & 0,072 & $-2,917$ & 0,004 \\
\hline Sikap Konsumen & 0,602 & 0,072 & 8,381 & 0,000 \\
\hline $\mathrm{F}_{\text {hitung }}$ & 38,975 & $\mathrm{n}$ & $=100$ & \\
\hline$F_{\text {tabel }}$ & 2,70 & Sig. & $=0.000$ & \\
\hline$t_{\text {tabel }}$ & 1,984 & $\mathrm{R}$ Squ & $e=0,549$ & \\
\hline Adjusted R square & 0,549 & & & \\
\hline
\end{tabular}

Sumber : Data Primer Diolah

Berdasarkan hasil analisis regresi berganda seperti terlihat pada Tabel 1, maka diperoleh persamaan regresi linear berganda sebagai berikut :

$$
\begin{gathered}
\mathrm{Y}=3,366+0,419 \mathrm{X}_{1}-0,201 \mathrm{X}_{2}+0,602 \mathrm{X}_{3}+\mathrm{e} \\
\text { Persamaan tersebut }
\end{gathered}
$$
menunjukkan bahwa koefisien regresi (b) mempunyai nilai positif untuk semua variabel dan signifikan pada $\propto<0,05$ yang berarti bahwa variable motivasi $\left(\mathrm{X}_{1}\right)$, persepsi $\left(\mathrm{X}_{2}\right)$, sikap konsumen $\left(\mathrm{X}_{3}\right)$ berpengaruh terhadap keputusan pembelian (Y) baik secara simultan maupun secara parsial.

Nilai koefisien determinasi (Adjusted $\mathrm{R}^{2}$ ) menunjukkan angka 0.549 atau 54\%. Hal ini berarti bahwa 5,4\% variasi naik turunnya keputusan pembelian mampu dijelaskan oleh 
variasi variable motivasi $\left(\mathrm{X}_{1}\right)$, persepsi $\left(\mathrm{X}_{2}\right)$,sikap konsumen $\left(\mathrm{X}_{3}\right)$. Sedangkan sisanya sebesar $46 \%$ dijelaskan oleh variabel lain di luar model.

Uji $\mathrm{F}$ digunakan untuk melihat signifikansi pengaruh antara variabel independen terhadap variabel dependen. Uji F dilakukan dengan membandingkan nilai $F_{\text {hitung }}$ dengan nilai $F_{\text {tabel }}$ pada taraf signifikansi 0,05. Berdasarkan hasil perhitungan regresi linear berganda yang disajikan pada tabel di atas, Nampak bahwa nilai $\mathrm{F}_{\text {hitung }}$ lebih besar dari nilai $F_{\text {tabel }}(38,975>2,70)$ hal ini berarti bahwa variable motivasi $\left(\mathrm{X}_{1}\right)$, persepsi $\left(\mathrm{X}_{2}\right)$, sikap konsumen $\left(\mathrm{X}_{3}\right)$ secara bersama-sama mempunyai pengaruh terhadap keputusan pembelian (Y).

Uji t digunakan untuk melihat pengaruh variabel independen terhadap variabel dependen secara parsial. Uji t dilakukan dengan membandingkan nilai $\mathrm{t}_{\text {hitung }}$ dengan nilai $\mathrm{t}$ tabel pada taraf signifikansi $\propto=0,05$. Berdasarkan ringkasan hasil perhitungan regresi linear berganda pada tabel di atas dapat diketahui bahwa secara parsial variable motivasi berpengaruh signifikan terhadap keputusan pembelian dengan bukti nilai $\mathrm{t}_{\text {hitung }}(5,756)>\mathrm{t}_{\text {tabel }}(1,984)$. Persepsi memiliki nilai $t_{\text {hitung }}(-2,917)<$ $t_{\text {tabel }}(1,984)$ artinya pada variabel ini berpengaruh negatif signifikan terhadap keputusan pembelian. Pada variabel sikap konsumen $(8,381)>t_{\text {tabel }}(1,984)$ artinya variable sikap konsumen memiliki pengaruh signifikan terhadap keputusan pembelian sepeda motor pada Dealer Astra Motor Palur

\section{Pembahasan}

Hasil analisis deskriptif dan pengujian hipotesis menunjukkan bahwa variable motivasi, persepsi, sikap konsumen secara bersama-sama berpengaruh signifikan terhadap keputusan pembelian dan secara parsial menunjukkan bahwa variable motivasi berpengaruh signifikan terhadap keputusan pembelian. Variabel persepsi berpengaruh negatif signifikan terhadap keputusan pembelian. Variabel sikap konsumen memiliki pengaruh signifikan terhadap keputusan pembelian.

\section{KESIMPULAN DAN SARAN}

\section{Kesimpulan}

1. Hasil penelitian menunjukkan bahwa motivasi, persepsi, serta sikap konsumen secara simultan memiliki hubungan yang signifikan terhadap keputusan pembelian, sehingga hipotesis yang diajukan terbukti kebenaranya. Hal ini ditunjukkan dalam hasil uji $\mathrm{F}$ yaitu $F_{\text {hitung }} 38,973>F_{\text {tabel }} 2,70$.

2. Hasil penelitian menunjukkan bahwa variabel Motivasi $\left(\mathrm{X}_{1}\right)$ secara parsial berpengaruh terhadap Keputusan Pembelian (Y). Hal ini dibuktikan dengan hasil uji signifikansi parsial dengan nilai $\mathrm{t}_{\text {hitung }}<\mathrm{t}_{\text {tabel }}(5,756>1,968)$.

3. Hasil penelitian menunjukkan bahwa variabel Persepsi (X2) secara parsial tidak berpengaruh terhadap Keputusan Pembelian (Y). Hal ini dibuktikan dengan hasil uji signifikansi parsial dengan nilai $\mathrm{t}_{\text {hitung }}<\mathrm{t}_{\text {tabel }}(-2,917<1,968)$.

4. Hasil penelitian menunjukkan bahwa variabel Sikap Konsumen (X3) secara parsial berpengaruh terhadap Keputusan Pembelian (Y). Hal ini dibuktikan dengan hasil uji signifikansi parsial dengan nilai $\mathrm{t}_{\text {hitung }}<\mathrm{t}_{\text {tabel }}(8,381>1,968)$

5. Berdasarkan uji analisis regresi linear berganda dapat diketahui bahwa nilai koefisien regresi variabel motivasi sebesar 5,756 dengan signifikansi 0,000 . Hal ini berarti bahwa motivasi berpengaruh positif dan signifikan terhadap keputusan pembelian pada Dealer Motor Astra Motor Palur. Nilai koefisien pada variabel persepsi sebesar $-0,917$ dengan signifikansi 0,004 . Hal ini berarti bahwa persepsi berpengaruh negatif dan signifikan terhadap keputusan 
pembelian pada Dealer Motor Astra Motor Palur. Nilai koefisiensi variabel sikap konsumen sebesar 8,381 dengan signifikansi 0,000 . Hal ini berarti bahwa variabel sikap konsumen berpengaruh positif dan signifikan terhadap keputusan pembelian pada Dealer Motor Astra Motor Palur.

6. Berdasarkan hasil analisis koefisien determinasi bahwa Adjusted $\mathrm{R}$ square $=0,535$ atau $53 \%$. Hal ini menunjukkan bahwa kontribusi semua variabel independent yaitu motivasi $\left(\mathrm{X}_{1}\right)$, persepsi $\left(\mathrm{X}_{2}\right)$ sikap konsumen $\left(\mathrm{X}_{3}\right)$ adalah sebesar 53\% sisanya sebesar $46 \%$ dipengaruhi oleh variabel lain yang tidak dijelaskan dalam penelitian ini yaitu perilaku konsumen yang lain seperti faktor kebudayaan, faktor sosial, faktor pribadi, dan faktor psikologis.

\section{Saran}

Disarankan Bagi pihak Honda Astra Motor Palur, perlu memperhatikan psikologi konsumen diantaranya dari segi motivasi, persepsi dan sikap konsumen salahsatunya dengan meningkatkan kualitas dari motor honda menjadi lebih baik lagi dengan menggunakan material yang lebih baik sehingga kualitas pada kendaraan meningkat.

\section{REFERENSI}

Arikunto, S. 2002. Prosedur Penelitian, Suatu Pendekatan Peraktek. Jakarta: PT. Rineka Cipta.

Handoko, T. Hani. 2001. Manajemen Personalia dan Sumberdaya Manusia. Edisi Kedua. BPFE: Yogyakarta.

Kotler, Philip, Amstrong, Garry. 1996. Principle of Marketing, Ninth Edition. prentice hall inc. Upper saddle river: New jersey.

Kotler, Philip. 2002. Manajemen Pemasaran. Jilid1. Edisi Milenium. Jakarta: Prehallindo.

Kotler, philip. 2005. Manajemen Pemasaran, jilid I dan II, PT. Indeks, jakartra.

Kotler, Philip dan Kevin L. Keller. 2009. Manajemen Pemasaran. Jakarta : Indeks Puri Media Kembangan.

Robbins, Stephen. 2006. Perilaku organisasi. PT Indeks: Kelompok Gramedia.

Schiffman, Leon. G; Leslie Lazar Kanuk. 2000. 7 th Edition prentice hall inc. Upper saddle river: New jersey.

Sigit, soehardi. 2002. Pemasaran praktis. Edisi ketiga. BPFE: Yogyakarta.

Simamora, Henry. 2002. Sumber daya manusia. STIE YKPN: Yogyakarta.

Supawi, Eny. 2011. Pengantar Ekonometrika. Idea Press. Yogyakarta.

Sutisna. 2003. Perilaku Konsumen dan Komunikasi Pemasaran. Bandung: PT.Remaja Rosdakarya.

Swasta, basu dan Handoko, T. Hani. 2000. Menejemen pemasaran analisis perilaku konsumen. Edisi kedua. Liberti: Yogyakarta.

Uma, Sekaran. 2006. Metodologi Penelitian Untuk Bisnis. Edisi Keempat, buku 1,

Lamb, dkk. 2001. Pemasaran Buku 2. Dialihbahasakan David Octarevia. Jakarta: Salemba Empat. 